\title{
Efficacy of Choline in Ameliorating Aflatoxicosis in Broiler Chickens
}

\author{
Ram Singh* \\ Avian Nutrition and Feed Technology Division, Central avian Research Institute, \\ Izatnagar-243122 (U.P.), CIRB, Hisar, India
}

*Corresponding author

\section{Keywords \\ Aflatoxicosis, \\ Broiler chicken, \\ Production \\ performance, \\ Choline}

Article Info

Accepted:

18 January 2019

Available Online:

10 February 2019

\section{A B S T R A C T}

The present study was undertaken to evaluate the efficacy of choline in ameliorating aflatoxicosis in broiler chickens. Day-old broiler chicks $(n=240)$ were divided into 6 treatment groups $\left(\mathrm{T}_{1}\right.$-control, basal diet; $\mathrm{T}_{2}-\mathrm{T}_{1}+250 \mathrm{ppb} \mathrm{AFB}_{1} ; \mathrm{T}_{3}-\mathrm{T}_{1}+200 \mathrm{ppm}$ Choline; $\mathrm{T}_{4}-\mathrm{T}_{1}+400 \mathrm{ppm}$ Choline; $\mathrm{T}_{5}-\mathrm{T}_{2}+200 \mathrm{ppm}$ Choline and $\mathrm{T}_{6^{-}} \mathrm{T}_{2}+400 \mathrm{ppm}$ Choline). Each diet was fed to 4 replicated groups of 10 birds each from day-old to 42 days of age. During overall growth period ( $0-6$ weeks), the $\mathrm{BWG}$ of control group $\left(\mathrm{T}_{1}\right)$ was higher $(\mathrm{P}<0.05)$ than that of toxin fed group $\left(\mathrm{T}_{2}\right)$. The $\mathrm{BWG}$ in $\mathrm{T}_{5}$ and $\mathrm{T}_{6}$ was higher $(\mathrm{P}<0.05)$ than that of toxin fed group $\left(\mathrm{T}_{2}\right)$ but lower $(\mathrm{P}<0.05)$ than that of control, indicating that addition of choline to the aflatoxin contaminated diet partially ameliorated the adverse effects of aflatoxicosis on body weight gain. The feed intake did not vary significantly among various treatment groups. The FCR in control group $\left(\mathrm{T}_{1}\right)$ was lower $(\mathrm{P}<0.05)$ than that of $\mathrm{T}_{2}$. The FCR in other treatment groups $\left(\mathrm{T}_{3}\right.$ to $\left.\mathrm{T}_{6}\right)$ was statistically similar to that of control. The relative weight of liver in control group $\left(\mathrm{T}_{1}\right)$ was lower $(\mathrm{P}<0.05)$ than that of aflatoxin fed group $\left(\mathrm{T}_{2}\right)$. The relative weight of liver in groups $\mathrm{T}_{5}$ and $\mathrm{T}_{6}$ was significantly $(\mathrm{P}<0.05)$ lower than that of toxin fed group $\left(\mathrm{T}_{2}\right)$, but significantly $(\mathrm{P}<0.05)$ higher than that of control $\left(\mathrm{T}_{1}\right)$. The relative weight of bursa of Fabricius in control group $\left(\mathrm{T}_{1}\right)$ was higher $(\mathrm{P}<0.05)$ than that of $\mathrm{T}_{2}$. The relative weight of bursa in group $\mathrm{T}_{6}$ was significantly $(\mathrm{P}<0.05)$ higher than that of $\mathrm{T}_{5}$, but lower than that of control $\left(\mathrm{T}_{1}\right)$. The total serum protein, cholesterolanduric acid content of control group $\left(\mathrm{T}_{1}\right)$ was higher $(\mathrm{P}<0.05)$ than that of $\mathrm{T}_{2}$. The total serum protein, cholesterol and uric acid content of groups $\mathrm{T}_{5}$ and $\mathrm{T}_{6}$ was higher $(\mathrm{P}<0.05)$ than that of $\mathrm{T}_{2}$ but lower than that of $\mathrm{T}_{1}$. The SGPT and SGOT activities in aflatoxin alone fed group $\left(\mathrm{T}_{2}\right)$ were higher $(\mathrm{P}<0.05)$ than that of control $\left(\mathrm{T}_{1}\right)$. The SGPT and SGOT value in groups $\mathrm{T}_{5}$ and $\mathrm{T}_{6}$ was lower $(\mathrm{P}<0.05)$ than that of $\mathrm{T}_{2}$ but higher than that of $\mathrm{T}_{1}$.It was concluded that aflatoxicosis caused by $250 \mathrm{ppb}$ level of dietary aflatoxin resulted in depression of growth, feed intake, feed conversion efficiency; enlargement of liver, regression of bursa, decreased total protein, cholesterol, uric acid, and increased level of SGPT and SGOT activity. Inclusion of choline to the $250 \mathrm{ppb}$ aflatoxin contaminated feed partially ameliorated the adverse effects of aflatoxicosis on production performance, organ weights and blood biochemistry in broiler chickens. 


\section{Introduction}

Contamination of poultry feeds with aflatoxin is one of the major problems associated with the feeding of poultry. Aflatoxin occurs over a wide variety of substrates of practical importance to poultry feeding (maize, rice, wheat, groundnut cake, cottonseed meal, sunflower cake, soybean meal and compounded feeds). Aflatoxins are a group of secondary metabolites produced by a certain species of fungus of the genus Aspergillus (especially A. flavus and A. parasiticus). These fungiare capable of growing and contaminating the grains and cereals at any time before and after the harvest, during storage, transportation and processing of feed ingredients and the formulated feeds after processing. The spores of the fungi remain dormant but when the level of moisture is more than 12 per cent with a temperature of $25-35^{\circ} \mathrm{C}$, with humidity of 80 percent and adequate aeration initiate their growth. Aflatoxin contamination of feedstuffs has been reported to be of a wide range from 1 to $900 \mu \mathrm{g} / \mathrm{kg}$ in commonly used ingredients as well as mixed feed samples in developing countries (Mohanamba et al., 2007). Aflatoxicosis in poultry causes lowered performance in terms of reduced weight gain, feed intake and feed efficiency (Silambarasan et al., 2013; Singh et al., 2015 ; Singh et al., 2015 ; Singh et al., 2016), reduced nutrient utilisation (Silambarasan et al., 2013), increased mortality (Khatke et al., 2012 ; Sharma et al., 2014), anemia (Singh et al., 2015 ; Singh et al., 2016), hepatotoxicosis and haemorrhage (Singh et al., 2015 ; Singh et al., 2016), altered biochemistry (Singh and Mandal 2013; Singh et al., 2013) and reduced immunity resulting in susceptibility to environmental and infectious agents (Khatke et al., 2012 $2^{\mathrm{a}}$ ) leading to severe economic loss, pathological changes in the liver, kidney and bile duct (Silambarsan et al., 2016; Khatke et al., 2012a). Poultry industry suffers greater economic losses due to the greater susceptibility of the species in comparison with other animals to the toxin apart from continuing intermittent occurrences in feeds (Thapa, 2008). As mycotoxins are one of the major factors suppressing poultry productivity and also product quality, control of their impact is critical (Oguz, 2011). Choline plays an essential role in fat metabolism in the liver. It prevents abnormal accumulation of fat (fatty livers) by promoting its transport as lecithin or by increasing the utilization of fatty acids in the liver itself (Xue et al., 2010). Choline is thus referred to as a "lipotropic" factor due to its function of acting on fat metabolism by hastening removal or decreasing deposition of fat in liver. In broiler liver, fat content was reduced by adding choline at $760 \mathrm{mg}$ per $\mathrm{kg}$ (345 mg per lb) of diet for birds fed different energy sources (Rao et al., 2001). Spires et al., (1982) found that supplemental choline could replace up to two-thirds of the supplemental methionine required in broiler diets from 0 to 47 days in diets containing $0.30 \%$ methionine and $0.43 \%$ cystine in the starter phase, and $0.25 \%$ and $0.42 \%$ methionine and cystine, respectively, in the finisher phase. Growth retardation and perosis result from choline deficiency in young poultry. Perosis is the primary clinical sign of a choline deficiency in chicks and turkey poults, whereas quail develop enlarged hocks and bowed legs (NRC, 1994). The objective of the present investigation was to test the efficacy of choline in ameliorating adverse effects of aflatoxicosis in broiler chickens.

\section{Materials and Methods}

\section{Production and analysis of aflatoxin}

Aflatoxin was produced using the fungal strain Aspergillus flavus NRRL 6513 that was obtained from U.S. Department of Agriculture, USA. To get the fresh spores, the 
culture was regularly subcultured on potato dextrose agar (PDA) medium slants and stored at $5^{\circ} \mathrm{C}$. Aflatoxin was produced on maize substrate. Fermentations were carried out in batches as per Shot well et al., (1966). The extraction and estimation of aflatoxin was done as per Pons et al., (1966). Aqueous acetone was used for extraction of the toxin. Aflatoxin contents were finally quantified using a UV spectrophotometer.

\section{Experimental design}

Experimental design was completely randomized design (CRD). There were six dietary treatments. Each dietary treatment had 4 replicates and each replicate had 10 chicks. The experiment was conducted in broiler chickens from day-old to 6 weeks of age. The various dietary treatments were prepared by mixing mouldy maize to get the desired concentration of $250 \mathrm{ppb} \mathrm{AFB}_{1}$ (Table 1).

\section{Biological experiment, feed formulation and analysis}

Day-old broiler chicks $(\mathrm{n}=240)$ were obtained from experimental hatchery, CARI, Izatnagar. The chicks were wing banded, weighed individually and distributed randomly into six groups. All birds were reared under standard management conditions from 0-6 weeks. All birds were fed with broiler starter ration from 1-21 days and broiler finisher ration from 22 to 42 days. The composition of broiler starter and finisher ration was as below: The starter diet with maize 55.5, Deoiled rice bran 1.88, soybean meal 31.0, guar corma 4 , rapeseed meal 4, fish meal 4.5, limestone 0.7, dicalcium phosphate 1.6 , common salt 0.2 , DL-methionine 0.07 , lysine 0.125 , TM premix 0.11 , vitamin premix 0.15 , B complex 0.015 , choline chloride 0.05 and coccidiostat $0.05 \%$; and finisher diet with maize 62.42 , Deoiled rice bran 2.01, soybean meal 20.5, guar corma 4, rapeseed meal 4, fish meal 4, limestone 0.5 , dicalcium phosphate 1.6, common salt 0.25 , DL-methionine 0.03, lysine 0.07 , TM premix 0.10 , vitamin premix 0.15 , B complex 0.015 , choline chloride 0.05 and coccidiostat $0.05 \%$ were formulated. TM premix supplied Mg, 300; Mn, 55; I, 0.4; Fe, 56; $\mathrm{Zn}, 30 ; \mathrm{Cu}, 4 \mathrm{mg} / \mathrm{kg}$ diet. Vitamin premix supplied Vit A, 8250 IU; Vit. D3, 1200 IU; Vit. K, 1mg per kg diet.B complex supplied Vit. $\mathrm{B}_{1}, 2 \mathrm{mg}$; Vit. $\mathrm{B}_{2}$, $4 \mathrm{mg}$; Vit. $\mathrm{B}_{12}, 10 \mathrm{mcg}$; niacin, 60mg; pantothenic acid, 10mg; choline, 500mg per $\mathrm{kg}$ diet. The starter diet contained $22.3 \%$ crude protein, 2,807 Kcal $\mathrm{ME} / \mathrm{kg}$, lysine $1.28 \%$, methionine $0.51 \%$, calcium $1.09 \%$ and available $\mathrm{P} 0.50 \%$.The corresponding values in finisher diet were $20.06 \%, 2,876 \mathrm{Kcal} / \mathrm{kg}, 1.04 \%, 0.43 \%, 1.09 \%$ and $0.42 \%$. The protein as per AOAC (1995) and calcium contents as per Talapatra et al., (1940) were estimated, while the concentration of lysine, methionine, available $\mathrm{P}$ and metabolizable energy value were calculated. Fortnightly individual body weight and feed consumption of each group were recorded and the FCR (feed: gain) was calculated. At the end of sixth week of experimental trial, ten birds per dietary treatment were sacrificed randomly in order to record relative (\% of body weight) weights of liver, heart, spleen and bursa of Fabricius. The blood samples from each treatment group were collected. The serum was separated and stored at $-20^{\circ} \mathrm{C}$ and analyzed for various biochemical parameters using commercial kit manufactured by Span Diagnostics Ltd, SACHIN, Surat.

\section{Statistical analysis}

The collected data was subjected to statistical analysis using Statistical Package for Social Sciences (SPSS Version 16.0). The recorded data were subjected to one-way analysis of variance with comparison among means was made by Duncan's multiple range test with significance level of $\mathrm{P}<0.05$. 


\section{Results and Discussion}

The data pertaining to production performance body weight gain (BWG), feed intake (FI) and feed conversion ratio (FCR) at different growth phases are presented in Table 2.

\section{Body weight gain (BWG)}

During starting growth phase (0-3 weeks), the BWG of broilers in control group $\left(\mathrm{T}_{1}\right)$ was higher $(\mathrm{P}<0.05)$ than that of aflatoxin fed group $\left(\mathrm{T}_{2}\right)$. The $\mathrm{BWG}$ in $\mathrm{T}_{3}$ and $\mathrm{T}_{4}$ was statistically similar to that of control $\left(\mathrm{T}_{1}\right)$. The BWG in $\mathrm{T}_{5}$ was statistically similar to that of toxin fed group $\left(\mathrm{T}_{2}\right)$. However, the BWG in $\mathrm{T}_{6}$ was statistically similar to that of control. During finisher phase (4-6 weeks), the BWG among various dietary treatments did not differ significantly. During overall growth period (0-6 weeks), the BWG of control group $\left(T_{1}\right)$ was higher $(\mathrm{P}<0.05)$ than that of toxin fed group $\left(\mathrm{T}_{2}\right)$. The BWG of $\mathrm{T}_{3}$ and $\mathrm{T}_{4}$ was statistically similar to that of control $\left(\mathrm{T}_{1}\right)$.The $\mathrm{BWG}$ in $\mathrm{T}_{5}$ and $\mathrm{T}_{6}$ was higher $(\mathrm{P}<0.05)$ than that of toxin fed group $\left(\mathrm{T}_{2}\right)$ but lower $(\mathrm{P}<0.05)$ than that of control, indicating that addition of choline at any level to the aflatoxin contaminated diet partially ameliorated the adverse effects of aflatoxicosis on body weight gain of broiler chickens. The present investigation indicated that the addition of $250 \mathrm{ppb}$ aflatoxin to the basal diet of broiler chickens resulted in significant decrease in body weight gain. The present study indicated that inclusion of 250 ppb of aflatoxin in the diet of broiler chickens resulted in significant reduction in BWG during 0-6 wk of growth trial. Significant reduction in BWG of broilers at $300 \mathrm{ppb}$ level of dietary aflatoxin was also reported by previous researchers (Silambarsan et al., 2013; Abaji 2012; Raju and Devegowda 2000). In the present study, incorporation of choline to the $250 \mathrm{ppb}$ aflatoxin contaminated feed partially ameliorated the adverse effects of aflatoxicosis on body weight gain of broiler chickens.

\section{Feed intake}

During starter phase (0-3wk), finisher phase (4-6 wk) and overall growth period (0-6 wk), the feed intake $(\mathrm{FI})$ in $\mathrm{T}_{1}$ did not differ $(\mathrm{P}<0.05)$ from other treatment groups. However, the FI during starter phase, finisher phase and overall growth period varied between 750.64 to $797.29,1864.77$ to 1984.63 and 2615.41 to 2772.39 , respectively. In all the three growth phases, the FI was numerically lowest in toxin fed groups. The results revealed that aflatoxin contamination in feed at $250 \mathrm{ppb}$ level resulted in decreased feed intake in broiler chickens. Decreased feed intake was also reported by Beura et al., (1993), who also reported reduced feed consumption in pure bred and commercial broiler chicken at 300 and $800 \mathrm{ppb}$, respectively. Significantly reduced feed consumption at $300 \mathrm{ppb}$ aflatoxin was also reported by Silambarasan et al., (2013); Abaji (2012) and Raju and Devegowda (2000). Several researchers (Kubena et al., 1990; Kubena et al., 1998; Ledoux et al., 1999; Verma et al., 2004; Santurio et al., 1999) also reported decreased feed consumption due to aflatoxin contamination ranging from 1 to 5 ppm. In the present study, inclusion of choline to the $250 \mathrm{ppb}$ aflatoxin contaminated feed ameliorated the adverse effects of aflatoxicosis on feed consumption of broiler chickens, however, the feed consumption was numerically lower than that of control.

\section{Feed conversion ratio (FCR)}

During starter phase (0-3wk), finisher phase (4-6 wk) and overall growth period (0-6 wk), the feed conversion ratio (FCR) of control group $\left(\mathrm{T}_{1}\right)$ was lower $(\mathrm{P}<0.05)$ than that of aflatoxin fed group $\left(\mathrm{T}_{2}\right)$. The FCR of groups 
$\mathrm{T}_{3}, \mathrm{~T}_{4}, \mathrm{~T}_{5}$ and $\mathrm{T}_{6}$ did not vary significantly from that of control. Deterioration of feed efficiency is a common feature of aflatoxicosis in poultry. In the present study, aflatoxin contamination in feed resulted in poor feed efficiency in broilers during 0-6 weeks of age. Silambarasan et al., (2013); Abaji (2012) and Raju and Devegowda (2000) also reported significantly poor feed efficiency in broiler chickens at $0.3 \mathrm{ppm}$ level of dietary aflatoxin. Similarly, other researchers have also reported a dose dependent significant reduction in feed efficiency due to presence of aflatoxin in diet (Verma et al., 2004; Reddy et al., 1982; Rosa et al., 2001). In the present study, inclusion of choline to the $250 \mathrm{ppb}$ aflatoxin contaminated feed ameliorated the adverse effects of aflatoxicosis on feed efficiency of broiler chickens.

\section{Organ weight}

The average value of relative organ weights (liver, heart, spleen and bursa of Fabricius) expressed as percentage of live weight were statistically analyzed and presented in Table 3.

\section{Liver}

The relative weight of liver (percent of live body weight) in $\mathrm{T}_{1}$ was lower $(\mathrm{P}<0.05)$ than that of aflatoxin fed groups $\left(\mathrm{T}_{2}\right)$.The relative weight of liver in treatment groups $T_{3}$ and $T_{4}$ was statistically similar to that of control $\left(\mathrm{T}_{1}\right)$. The relative weight of liver in groups $T_{5}$ and $\mathrm{T}_{6}$ was significantly $(\mathrm{P}<0.05)$ lower than that of toxin fed group $\left(\mathrm{T}_{2}\right)$, but significantly $(\mathrm{P}<0.05)$ higher than that of control $\left(\mathrm{T}_{1}\right)$. The relative weight of liver in groups $T_{5}$ was statistically $(\mathrm{P}<0.05)$ higher than that of $\mathrm{T}_{6}$. In the present study, aflatoxin contamination in the diet of broiler chickens resulted in increased $(\mathrm{P}<0.05)$ relative weight of liver. Significant increase in the relative weight of liver due to aflatoxin feeding (0.3 to $5 \mathrm{ppm})$ was also reported earlier (Silambarsan 2011; Giambrone et al., 1985'; Giambrone et al., $1985^{\text {b; }}$ Kubena et al., 1998; Raju and Devegowda 2000; Rosa et al., 2001; Miazzo et al., 2000; Sapcota et al., 2007). In the present study, supplementation of choline to the aflatoxin contaminated diet $\left(\mathrm{T}_{4}\right.$ and $\left.\mathrm{T}_{5}\right)$ partially ameliorated the adverse effects of aflatoxicosis on relative weight of liver. The higher level of choline was more efficaceous in ameliorating the adverse effects of aflatoxicosis on relative liver weight in broiler chickens.

\section{Heart}

The relative weight of heart among various dietary treatments did not differ significantly i.e. addition of aflatoxin to feed did not produce any significant effect on relative heart weight. Contrary to this, significant increase in the relative heart weight due to dietary addition of aflatoxin ranging from 3 to 5 ppm was reported by several researchers (kubena et al., 1990; Kubena et al., 1998; Bailey et al., 1998; Leudoux et al., 1999; Rosa et al., 2001). In the present study, no effect of dietary aflatoxin on relative weight of heart could be due to low level of aflatoxin in feed. Also, supplementation of choline did not show any significant effect on relative weight of heart.

\section{Spleen}

There was no significant difference in relative weight of spleen among various dietary treatments i.e. addition of aflatoxin to feed did not produce any significant effect on relative spleen weight. Contrary to this, significant increase in relative spleen weight due to dietary aflatoxin content ranging from 3.5 to 5 ppm has also been reported by earlier researchers (Kubena et al., 1990; Bailey et al., 1998; Kubena et al., 1998 and Rosa et al., 
2001).In the present study, no significant effect of aflatoxin addition on the relative weight of spleen could be due to low level of aflatoxin in the feed. Also, supplementation of choline did not show any significant effect on relative weight of spleen.

\section{Bursa of fabricius}

The relative weight of bursa of Fabricius in $\mathrm{T}_{1}$ was higher $(\mathrm{P}<0.05)$ than that of aflatoxin fed group $\left(\mathrm{T}_{2}\right)$. The relative weight of bursa in groups $T_{3}$ and $T_{4}$ was statistically similar to that of control. The relative weight of bursa of group $\mathrm{T}_{5}$ was statistically similar to that of aflatoxin fed group $T_{2}$, indicating that addition of choline at $200 \mathrm{ppm}$ level to the $250 \mathrm{ppb}$ aflatoxin contaminated feed did not ameliorate the adverse effect of aflatoxicosis on immunity of birds. The relative weight of bursa in group $\mathrm{T}_{6}$ was significantly $(\mathrm{P}<0.05)$ higher than that of $\mathrm{T}_{5}$, but lower than that of control $\left(\mathrm{T}_{1}\right)$.

In the present study, aflatoxin contamination in feed resulted in significant $(\mathrm{P}<0.05)$ reduction in relative weight of bursa. Silambarsan (2011) also reported a significant decrease in the relative weight of bursa at 300 ppb level of dietary aflatoxin. Significant reduction in the relative weight of bursa was also reported in chicks receiving $2 \mathrm{ppm}$ of aflatoxin (Verma et al., 2004). A severe and significant regression of bursa in broilers was observed by Thaxton et al., (1974) at 0.75 ppm and higher level of aflatoxin. Similar results have also been reported by Chattopadhyay et al., (1985); Gopi (2006); Beura (1988) who also observed a significant reduction in bursal weight due to dietary aflatoxin. In the present study, supplementation of choline at $400 \mathrm{ppm}$ level to the $250 \mathrm{ppb}$ aflatoxin contaminated feed partially ameliorated the ill effects of aflatoxicosis on bursa of Fabricius in birds.

\section{Effect on biochemical parameter}

The data of various biochemical parameters (total serum protein, cholesterol, uric acid, SGPT and SGOT) was statistically analyzed and the mean values are presented in Table 4.

\section{Total serum protein}

The total serum protein content of control group $\left(\mathrm{T}_{1}\right)$ was higher $(\mathrm{P}<0.05)$ than that of aflatoxin fed group $\left(\mathrm{T}_{2}\right)$. The serum protein content in groups $\mathrm{T}_{3}$ and $\mathrm{T}_{4}$ was statistically similar to that of control. The serum protein content of group $\mathrm{T}_{5}$ and $\mathrm{T}_{6}$ was higher $(\mathrm{P}<0.05)$ than that of $\mathrm{T}_{2}$ but lower than that of $\mathrm{T}_{1}$. The results of the present investigation showed that administration of aflatoxin at $250 \mathrm{ppb}$ level of contamination in feed caused significant $(\mathrm{P}<0.05)$ reduction in serum protein content. A significant decrease in serum protein due to feeding aflatoxin contaminated diet has also been reported by earlier workers (Kubena et al., 1998, Ledoux et al., 1999; Raju and Devegowda 2000; Gopi 2006; Silambarasan 2011). The decrease in total serum protein by aflatoxin feeding has been reported due to reduced content of albumin and $\beta$ globulin (Pier 1992). Reduced value of serum albumin and globulin has also been reported by Huff et al., (1992). Other researchers reported that decrease in serum protein by aflatoxin feeding was attributed to failure in digestion and absorption of protein in gastro-intestinal tract (Voight et al., 1980) and inhibition of protein synthesis due to aflatoxin contamination in diet (Sarasin and Moule 1973). Groopman et al., (1996) also reported that the decline in serum protein may be due to decline in protein synthesis by forming adduct with DNA, RNA and protein and inhibit RNA synthesis and DNAdependent RNA polymerase activity as well as causing degranulation of endoplasmic reticulum. In the present study, incorporation of choline to the $250 \mathrm{ppb}$ aflatoxin 
contaminated feed partially ameliorated the adverse effects of aflatoxicosis on total serum protein content in broiler chickens.

\section{Cholesterol}

With regard to serum cholesterol, the cholesterol content of control group $\left(\mathrm{T}_{2}\right)$ was lower $(\mathrm{P}<0.05)$ than that of control $\left(\mathrm{T}_{1}\right)$. The cholesterol content in groups $\mathrm{T}_{3}$ and $\mathrm{T}_{4}$ was statistically similar to that of control. The cholesterol content of group $\mathrm{T}_{5}$ and $\mathrm{T}_{6}$ was higher $(\mathrm{P}<0.05)$ than that of $\mathrm{T}_{2}$ but lower than that of $T_{1}$. The results revealed that aflatoxin contamination of feed at $250 \mathrm{ppb}$ level resulted in reduced $(\mathrm{P}<0.05)$ serum cholesterol content of broiler chickens. These results are in agreement with those reported by earlier workers (Bailey et al., 1998; Kececi et al., 1998; Raju and Devegowda, 2000; Ahamad, 2000). In the present study, inclusion of choline to the $250 \mathrm{ppb}$ aflatoxin contaminated diet partially alleviated the adverse effects of aflatoxicosis on serum cholesterol in birds.

\section{Serum uric acid}

The serum uric acid content of control group $\left(\mathrm{T}_{1}\right)$ was lower $(\mathrm{P}<0.05)$ than that of aflatoxin fed group $\left(\mathrm{T}_{2}\right)$. The uric acid content in groups $T_{3}$ and $T_{4}$ was statistically similar to that of control. The uric acid value in groups $\mathrm{T}_{5}$ and $\mathrm{T}_{6}$ was higher $(\mathrm{P}<0.05)$ than that of $\mathrm{T}_{2}$ but lower $(\mathrm{P}<0.05)$ than that of $\mathrm{T}_{1}$. The results revealed that addition of $250 \mathrm{ppb}$ aflatoxin to the diet reduced $(\mathrm{P}<0.05)$ the serum uric acid content in broiler chickens. Oguz et al., (2000) reported that serum uric acid was decreased when $50 \mathrm{ppb}$ aflatoxin containing diet was fed to broiler chickens. Denliet al., (2009) also observed that $1 \mathrm{ppm}$ aflatoxin containing diet resulted in decrease in serum uric acid concentration. Safameher (2008) also reported that significant reduction in serum uric acid with $0.5 \mathrm{ppm}$ of aflatoxin containing diet. A significant decrease in the uric acid concentration was also reported by several other researchers (Bailey et al., 1998; Kececi et al., 1998). In the present study, addition of choline to the $250 \mathrm{ppb}$ aflatoxin contaminated feed partially ameliorated the adverse effects of aflatoxicosis on uric acid in broiler chickens.

\section{Serum Glutamic Pyruvic Transferase (SGPT)}

The SGPT activities in aflatoxin alone fed group $\left(\mathrm{T}_{2}\right)$ were higher $(\mathrm{P}<0.05)$ than that of control $\left(\mathrm{T}_{1}\right)$. The SGPT value in groups $\mathrm{T}_{3}$ and $\mathrm{T}_{4}$ was statistically similar to that of control. The SGPT value in groups $\mathrm{T}_{5}$ and $\mathrm{T}_{6}$ was lower $(\mathrm{P}<0.05)$ than that of $\mathrm{T}_{2}$ but higher than that of $T_{1}$. In the present study, $250 \mathrm{ppb}$ level of dietary aflatoxin resulted in increased activities of SGPT. Denli et al., (2009) and Eraslanet al., (2006) also reported an increase in the activity of SGPT with $1 \mathrm{ppm}$ of aflatoxin contaminated diet. Increased level of SGPT activity due to aflatoxin was also reported by several researchers (Shi et al., 2009; Kermanshahi et al., 2009). In the present study, addition of choline to the 250 ppb aflatoxin contaminated diet partially alleviated the ill effects of aflatoxicosis on SGPT activity in broiler chickens.

\section{Serum Glutamic OxaloaceticTransferase (SGOT)}

The SGOT activities in aflatoxin alone fed group $\left(\mathrm{T}_{2}\right)$ were higher $(\mathrm{P}<0.05)$ than that of control $\left(\mathrm{T}_{1}\right)$. The SGOT value in groups $\mathrm{T}_{3}$ and $\mathrm{T}_{4}$ was statistically similar to that of control. The SGOT value in groups $\mathrm{T}_{5}$ and $\mathrm{T}_{6}$ was lower $(\mathrm{P}<0.05)$ than that of $\mathrm{T}_{2}$ but higher than that of $T_{1}$. The results revealed that aflatoxin contamination at $250 \mathrm{ppb}$ level in the feed resulted in increased $(\mathrm{P}<0.05)$ SGOT activity. Denli et al., (2009) and Eraslan et al., (2006) also reported an increase in the SGOT 
activity with $1 \mathrm{ppm}$ of aflatoxin contaminated diet. Safameher (2008) also observed elevated SGOT activity in chickens with $0.5 \mathrm{ppm}$ of aflatoxin contaminated diet. Increased activities of SGOT due to dietary aflatoxin were also reported by Shi et al., (2009); Raju and Devegowda (2000). The present study revealed that inclusion of choline to the 250 ppb aflatoxin contaminated diet partially ameliorated the ill effects of aflatoxicosis on SGOT activity in birds.

Table.1 Experimental group and treatments

\begin{tabular}{|l|l|}
\hline Group & Dietary treatment \\
\hline $\mathbf{T}_{\mathbf{1}}$ & Basal diet (Control) \\
\hline $\mathbf{T}_{\mathbf{2}}$ & $\mathrm{T}_{1}+250 \mathrm{ppb}$ AFB \\
\hline $\mathbf{T}_{3}$ & $\mathrm{~T}_{1}+200 \mathrm{ppm}$ Choline \\
\hline $\mathbf{T}_{\mathbf{4}}$ & $\mathrm{T}_{1}+400 \mathrm{ppm}$ Choline \\
\hline $\mathbf{T}_{\mathbf{5}}$ & $\mathrm{T}_{2}+200 \mathrm{ppm}$ Choline \\
\hline $\mathbf{T}_{\mathbf{6}}$ & $\mathrm{T}_{2}+400 \mathrm{ppm}$ Choline \\
\hline
\end{tabular}

Table.2 Effect of aflatoxin and choline supplementation on body weight gain, feed consumption and FCR of broiler chickens between 1 to 42 days of age

\begin{tabular}{|c|c|c|c|}
\hline Treatments & $0-3$ wk & 4-6 wk & $0-6$ wk \\
\hline \multicolumn{4}{|c|}{ Body weight gain (g/bird) } \\
\hline $\mathrm{T}_{1}$ & $479.13 \pm 7.62^{b}$ & $971.12 \pm 8.47^{\mathrm{a}}$ & $1450.26 \pm 10.47^{\mathrm{c}}$ \\
\hline $\mathbf{T}_{2}$ & $409.68 \pm 18.78^{a}$ & $797.41 \pm 16.37^{\mathrm{a}}$ & $1203.16 \pm 29.84^{\mathrm{a}}$ \\
\hline $\mathbf{T}_{3}$ & $471.91 \pm 7.95^{\mathrm{b}}$ & $799.04 \pm 175.29^{\mathrm{a}}$ & $1451.55 \pm 22.73^{\mathrm{c}}$ \\
\hline $\mathbf{T}_{4}$ & $460.60 \pm 19.60^{b}$ & $993.44 \pm 22.33^{\mathrm{a}}$ & $1454.04 \pm 40.73^{\mathrm{c}}$ \\
\hline $\mathbf{T}_{5}$ & $444.54 \pm 14.56^{\mathrm{ab}}$ & $885.39 \pm 15.18^{\mathrm{a}}$ & $1329.93 \pm 25.91^{\mathrm{b}}$ \\
\hline $\mathbf{T}_{6}$ & $463.18 \pm 6.75^{\mathrm{b}}$ & $930.36 \pm 25.46^{\mathrm{a}}$ & $1393.60 \pm 28.17^{\mathrm{bc}}$ \\
\hline \multicolumn{4}{|c|}{ Feed intake (g/bird) } \\
\hline $\mathbf{T}_{1}$ & $778.52 \pm 22.03^{\mathrm{a}}$ & $1984.63 \pm 38.17^{\mathrm{a}}$ & $2763.15 \pm 51.79^{a}$ \\
\hline $\mathbf{T}_{2}$ & $750.64 \pm 19.41^{\mathrm{a}}$ & $1864.77 \pm 22.73^{\mathrm{a}}$ & $2615.41 \pm 26.46^{\mathrm{a}}$ \\
\hline $\mathbf{T}_{3}$ & $793.32 \pm 13.34^{\mathrm{a}}$ & $1979.07 \pm 24.13^{\mathrm{a}}$ & $2772.39 \pm 33.59^{\mathrm{a}}$ \\
\hline $\mathbf{T}_{4}$ & $768.59 \pm 6.62^{\mathrm{a}}$ & $1967.74 \pm 30.21^{\mathrm{a}}$ & $2736.33 \pm 27.98^{\mathrm{a}}$ \\
\hline $\mathbf{T}_{5}$ & $797.29 \pm 11.26^{\mathrm{a}}$ & $1930.98 \pm 63.12^{\mathrm{a}}$ & $2728.27 \pm 72.57^{\mathrm{a}}$ \\
\hline$T_{6}$ & $789.07 \pm 14.47^{\mathrm{a}}$ & $1936.08 \pm 63.50^{\mathrm{a}}$ & $2725.16 \pm 62.16^{\mathrm{a}}$ \\
\hline \multicolumn{4}{|c|}{ Feed conversion ratio $(F C R)$} \\
\hline$T_{1}$ & $1.623 \pm 0.02^{\mathrm{a}}$ & $2.043 \pm 0.03^{\mathrm{a}}$ & $1.904 \pm 0.02^{\mathrm{a}}$ \\
\hline $\mathbf{T}_{2}$ & $1.846 \pm 0.09^{b}$ & $2.341 \pm 0.05^{\mathrm{b}}$ & $2.179 \pm 0.06^{\mathrm{b}}$ \\
\hline $\mathbf{T}_{3}$ & $1.683 \pm 0.04^{\mathrm{ab}}$ & $2.023 \pm 0.05^{\mathrm{a}}$ & $1.912 \pm 0.04^{\mathrm{a}}$ \\
\hline $\mathbf{T}_{4}$ & $1.681 \pm 0.07^{\mathrm{ab}}$ & $1.982 \pm 0.03^{\mathrm{a}}$ & $1.886 \pm 0.04^{\mathrm{a}}$ \\
\hline $\mathbf{T}_{5}$ & $1.797 \pm 0.04^{\mathrm{ab}}$ & $2.182 \pm 0.07^{\mathrm{ab}}$ & $2.051 \pm 0.04^{\mathrm{ab}}$ \\
\hline $\mathbf{T}_{6}$ & $1.703 \pm 0.03^{\mathrm{ab}}$ & $2.088 \pm 0.09^{\mathrm{a}}$ & $1.958 \pm 0.06^{\mathrm{a}}$ \\
\hline
\end{tabular}

Values bearing different superscripts in a column differ significantly $(\mathrm{P}<0.05)$ 
Table.3 Effect of aflatoxin and choline supplementation on relative organ weights (\% of live weight) of broiler chickens fed at 1 to 42 days of age

\begin{tabular}{|c|c|c|c|c|}
\hline Treatments & Liver & Heart & Spleen & Bursa \\
\hline $\mathbf{T}_{\mathbf{1}}$ & $2.36 \pm 0.03^{\mathrm{a}}$ & $0.60 \pm 0.00^{\mathrm{a}}$ & $0.31 \pm 0.02^{\mathrm{a}}$ & $0.28 \pm 0.01^{\mathrm{c}}$ \\
\hline $\mathbf{T}_{\mathbf{2}}$ & $3.54 \pm 0.02^{\mathrm{d}}$ & $0.61 \pm 0.00^{\mathrm{a}}$ & $0.31 \pm 0.01^{\mathrm{a}}$ & $0.15 \pm 0.00^{\mathrm{a}}$ \\
\hline $\mathbf{T}_{\mathbf{3}}$ & $2.43 \pm 0.17^{\mathrm{a}}$ & $0.60 \pm 0.00^{\mathrm{a}}$ & $0.30 \pm 0.01^{\mathrm{a}}$ & $0.31 \pm 0.01^{\mathrm{c}}$ \\
\hline $\mathbf{T}_{\mathbf{4}}$ & $2.38 \pm 0.03^{\mathrm{a}}$ & $0.60 \pm 0.01^{\mathrm{a}}$ & $0.31 \pm 0.01^{\mathrm{a}}$ & $0.29 \pm 0.01^{\mathrm{c}}$ \\
\hline $\mathbf{T}_{\mathbf{5}}$ & $3.16 \pm 0.03^{\mathrm{c}}$ & $0.60 \pm 0.01^{\mathrm{a}}$ & $0.32 \pm 0.01^{\mathrm{a}}$ & $0.17 \pm 0.00^{\mathrm{a}}$ \\
\hline $\mathbf{T}_{\mathbf{6}}$ & $2.80 \pm 0.11^{\mathrm{b}}$ & $0.60 \pm 0.00^{\mathrm{a}}$ & $0.30 \pm 0.01^{\mathrm{a}}$ & $0.20 \pm 0.00^{\mathrm{b}}$ \\
\hline
\end{tabular}

Values bearing different superscripts in a column differ significantly $(\mathrm{P}<0.05)$

Table.4 Effect of aflatoxin and choline on blood biochemical parameters of broiler chickens

\begin{tabular}{|c|c|c|c|c|c|}
\hline Treatments & $\begin{array}{c}\text { Total } \\
\text { protein } \\
(\mathbf{g} / \mathbf{d l})\end{array}$ & $\begin{array}{c}\text { Cholesterol } \\
(\mathbf{m g} / \mathbf{d l})\end{array}$ & $\begin{array}{c}\text { Uric Acid } \\
(\mathbf{m g} / \mathbf{d l})\end{array}$ & $\begin{array}{c}\text { SGPT } \\
(\mathbf{I U} / \mathbf{L})\end{array}$ & $\begin{array}{c}\text { SGOT } \\
(\mathbf{I U} / \mathbf{L})\end{array}$ \\
\hline $\mathbf{T}_{\mathbf{1}}$ & $6.74 \pm 0.08^{\mathrm{c}}$ & $209.67 \pm 1.74^{\mathrm{c}}$ & $8.15 \pm 0.11^{\mathrm{c}}$ & $39.41 \pm 1.04^{\mathrm{a}}$ & $139.47 \pm 2.47^{\mathrm{a}}$ \\
\hline $\mathbf{T}_{\mathbf{2}}$ & $4.56 \pm 0.09^{\mathrm{a}}$ & $156.54 \pm 2.18^{\mathrm{a}}$ & $5.88 \pm 0.09^{\mathrm{a}}$ & $52.39 \pm 0.79^{\mathrm{c}}$ & $249.94 \pm 4.08^{\mathrm{c}}$ \\
\hline $\mathbf{T}_{\mathbf{3}}$ & $6.77 \pm 0.07^{\mathrm{c}}$ & $210.67 \pm 1.43^{\mathrm{c}}$ & $8.12 \pm 0.12^{\mathrm{c}}$ & $39.35 \pm 1.03^{\mathrm{a}}$ & $140.32 \pm 1.86^{\mathrm{a}}$ \\
\hline $\mathbf{T}_{\mathbf{4}}$ & $6.78 \pm 0.10^{\mathrm{c}}$ & $211.15 \pm 1.89^{\mathrm{c}}$ & $8.06 \pm 0.07^{\mathrm{c}}$ & $39.40 \pm 0.95^{\mathrm{a}}$ & $138.60 \pm 2.34^{\mathrm{a}}$ \\
\hline $\mathbf{T}_{\mathbf{5}}$ & $5.71 \pm 0.17^{\mathrm{b}}$ & $186.76 \pm 6.17^{\mathrm{b}}$ & $6.35 \pm 0.15^{\mathrm{b}}$ & $48.75 \pm 1.00^{\mathrm{b}}$ & $195.08 \pm 3.12^{\mathrm{b}}$ \\
\hline $\mathbf{T}_{\mathbf{6}}$ & $5.70 \pm 0.19^{\mathrm{b}}$ & $186.59 \pm 8.52^{\mathrm{b}}$ & $6.44 \pm 0.14^{\mathrm{b}}$ & $48.50 \pm 1.30^{\mathrm{b}}$ & $190.27 \pm 4.48^{\mathrm{b}}$ \\
\hline
\end{tabular}

Values bearing different superscripts in a column differ significantly $(\mathrm{P}<0.05)$

It was concluded that aflatoxicosis caused by $250 \mathrm{ppb}$ level of dietary aflatoxin resulted in depression of growth, feed intake, feed conversion efficiency; enlargement of liver, regression of bursa, decreased total protein, cholesterol, uric acid, and increased level of SGPT and SGOT activity. Inclusion of choline to the $250 \mathrm{ppb}$ aflatoxin contaminated feed partially ameliorated the adverse effects of aflatoxicosis on production performance, organ weights and blood biochemistry in broiler chickens.

\section{References}

Abaji P K. 2012. Efficacy of Saccharomyces cerevisiae and mannan oligosaccharides (MOS) in counteracting aflatoxicosis in broiler chickens. M.V.Sc. Thesis,
Submitted to Deemed University, IVRI, Izatnagar.

Ahamad D B. 2000. Pathology of citrinin mycotoxicosis in broiler chicken. M.V.Sc. Thesis, Tamil Nadu Veterinary and Animal Sciences University, Chennai, Tamil Nadu, India.

AOAC. 1995. Official Methods of Analysis. Association of Official Analytical Chemists, Washington DC, USA.

Bailey R H, Kubena L F, Harvey R B, Buckley S A and Rottinghaus G E. 1998.Efficacy of various inorganic sorbents to reduce the toxicity of aflatoxin and T-2 toxin in broiler chicken. Poultry Science 77:1623-30.

Beura C K, Johri T S, Sadagopan V R and Panda B K. 1993.Interaction of dietary protein level on dose-response 
relationship during aflatoxicosis in commercial broilers. Indian Journal of Poultry Science 28:170-77.

Denli M, Blandon J C, Guynot M E, Salado S and Perez J F. 2009. Effects of dietary Afladetox on performance, serum biochemistry, histopathological changes and aflatoxin residues in broilers exposed to aflatoxin B1. Poultry Science88: 1444-51.

Eraslan G, Essiz D, Akdogan M, Karaoz E, Onuc M and Ozyildiz Z. (2006). Efficacy of dietary sodium bentonite against subchronic exposure to dietary aflatoxin in broilers. Bulletin of the veterinary Institute of Pulaway50: 107112.

Giambrone J J, Diener U L, Davis N D, Panangala V S, Hoerr F J. $1985^{\mathrm{b}}$ Effects of purified aflatoxin on broiler chickens.Poultry Science64: 852-58.

Giambrone J J, Diener U L, Davis N D, Panangala V S, Hoerr FJ. 1985 ${ }^{\mathrm{a}}$. Effects of purified aflatoxin on turkeys. Poultry Science64: 859-65.

Gopi K. 2006. Influence of melatonin on aflatoxicosis in broiler chickens. M.V.Sc. thesis, IVRI, Izatnagar.

Groopman J D, Wang J S and Schol L P. 1996. Molecular biomarkers for aflatoxin : from adducts to gene mutations to human liver cancer. Canadian Journal of Physiology and Pharmacology74: 203-209.

Huff W E, Kubena L F, Harvey R B and Phillips T D. 1992 Efficacy of hydrated sodium alluminosilicate to reduce the individual and combined toxicity of aflatoxin and ochratoxin A. Poultry Science 71: 64-69.

Kececi T, Oguz H, Kurtoglu V and Demet O. 1998. Effects of polyvynylpolypyrrolidone, synthetic zeolite and bentonite on serum biochemical and haematological characters of broiler chickens during aflatoxicosis. British Poultry Science 39: 452-58.

Kermanshahi H, Hazegh A R and Afali. 2009. Effect of sodium bentonite in broiler chickens fed diets contaminated with Aflatoxins B1. Journal of Animal and Veterinary Advances8 (8): 1631-36.

Khatke, P.A., Singh, R. and Mandal, A.B. $2012^{a}$. Efficacy of biological adsorbents to ameliorate aflatoxicosis in broiler chicken: Effect on immune response and histopathology of liver. Indian Journal of Poultry Science, 48(1):27-32.

Khatke, P.A., Singh, R., Mandal, A.B. and Tyagi, P.K. $2012^{\mathrm{b}}$. Evaluation of the ability of Saccharomyces cerevisiae and mannan oligosaccharides to ameliorate the adverse effects of aflatoxin $B_{1}$ in broiler chickens. Indian Journal of Poultry Science, 47(2):176-182.

Kubena L F, Harvey R B, Phillips T D and Huff WE. 1998. Modulation of aflatoxicosis in growing chickens by dietary addition of a hydrated sodium calcium aluminosilicate. Poultry Science67: 106.

Kubena L F, Harvey R B, Phillips T D, Corrier D E and Huff W E. 1990. Diminution of aflatoxicosis in growing chickens by dietary addition of a hydrated sodium calcium aluminosilicate. Poultry Science69: 727-35.

Ledoux D R, Rottinghaus G E, Bermudaz A J and Alonso-Debolt M. 1999. Efficacy of a hydrated calcium aluminosilicate to ameliorate the toxic effects of aflatoxin in broiler chicks. Poultry Science 78: 204-98.

Miazzo R, Rosa C A R, Dequeiroz-Carvalho E C, Mangoli C, Chiacchiera S M, Palacio G, Saenz M, Kikot A, Basaldella E and Dalcero A. 2000. Efficacy of synthetic of synthetic zeolite to reduce the toxicity of aflatoxin in broiler chicks. Poultry Science 79: 1-6.

Mohanamba T., Rao M R and Habibi S M M. (2007) Aflatoxin contamination in animal feed. Indian Veterinary Journal 84(4): 416-420.

NRC. 1994. Nutrient Requirement of Poultry (Ninth Rev. Ed.). National Academy Press, Washington, D.C.

Oguz H, Kececi T, Birdane Y O, Onder F and Kurtoglu V. 2000.Effect of clinoptilolite 
on serum biochemical and haematological characters of broiler chickens during experimental aflatoxicosis. Research in Veterinary Science69: 89-93.

Oguz, H. (2011). A review from experimental trials on detoxification of aflatoxin in poultry feed. Eurasian J. Vet. Sci., 27 (1): 1-12.

Pier A C. 1992. Major biological consequences of aflatoxicosis in animal production. Journal of Animal Science 70(12): 3964-77.

Pons D, Cucullu A P, Lee L S, Robertson J A and Goldblatt L A. 1966. Determination of aflatoxins in agricultural products: Use of aqueous acetone for extraction. Journal of Analytical Chemistry 49: 544-52.

Raju M V L N and Devegowda G. 2000. Influence of esterified glucomannan on performance and organ morphology, serum biochemistry and hematology in broilers exposed to individual and combined mycotoxicosis (aflatoxin, ochratoxin and T-2 toxin). British Poultry Science 41: 640-50.

Rao S.V. R., Sunder G.S., Reddy M.R., Praharaj N.K., Raju M.V.L.N. and Panda A.K. (2001). Effect of supplementary choline on the performance of broiler breeders fed on different energy sources. Br. Poult. Sci. 42, 362-367.

Reddy R A, Reddy V R, Rao P V and Yadagiri B. 1982.Effect of experimentally induced aflatoxicosis on the performance of commercial broiler chicks. Indian Journal of Animal Science, 52: 405-10.

Rosa C A R, Miazzo R, Magnoli C, Salvano M, Chiacchiera S M, Ferrero S, Saenz M, Carvalho E C Q and Dalcero A. 2001. Evaluation of the efficacy of bentonite from the south of Argentina to ameliorate the toxic effects of aflatoxin in broilers. Poultry Science 80: 139-44.

Safameher A. 2008. Effects of clinoptilolite on performance, Biochemical parameters,
Hepatic Lesions in Broiler Chickens during aflatoxicosis. Journal of Animal and Veterinary Advances, 7(4): 381-88.

Santurio J M, Mallmann C A, Rosa A P, Appel G, Heer A, Dageforde S and Bottcher M. 1999. Effect of sodium bentonite on the performance and blood variables of broiler chickens intoxicated with aflatoxins. British Poultry Science, 40:115-19.

Sapcota D, Islam R and Baruah K K. 2007. Protective efficacy of dietary methionine in experimental aflatoxicosis in broilers. Indian Journal of Animal Sciences, 77: 1170-72.

Sarasin A and Moule Y. 1973. Inhibition of in vivo protein synthesis by aflatoxin $\mathrm{B}_{1}$ derivatives. FEBS Letter, 32:347.

Sharma M, Singh R, Mandal A B and Gupta V P 2014 Efficacy of zinc in amelioration of aflatoxicosis in broiler chickens. Indian Journal of Animal Sciences, 84(3):311-15.

Shi Y, Xu Z, Sun Y, Wang C and Feng J. 2009. Different types of montmorillonite on growth performance and serum profiles of broiler chickens during aflatoxicosis. Turkey Journal of Veterinary Animal Science, 33(1):15-20.

Shotwell O L, Hesseltine C V, Stubblefield R D and Sorenson WG. 1996. Production of aflatoxin on rice. Applied Microbiology, 14:425-29.

Silambarasan S, Singh R and Mandal A B. 2013. Evaluation of the ability of adsorbents to ameliorate the adverse effects of aflatoxin $\mathrm{B}_{1}$ in broiler chickens. Indian Journal of Animal Sciences, 83:73-77.

Silambarasan S, Singh R and Mandal A B. 2016. Evaluation of adsorbents to ameliorate the adverse effects of aflatoxin $\mathrm{B}_{1}$ on blood biochemicals, immune response and histopathology of liver in broiler chickens. Indian Journal of Poultry Science, 50(3):267-71.

Silambarsan S. 2011. Efficacy of diatomaceous earth, sodium bentonite and zeolite as aflatoxin adsorbents in broiler chickens. 
M. V. Sc. Thesis. IVRI, Izatnagar.

Singh R and Mandal A B. 2013. Efficacy of ascorbic acid and butylated hydroxyanisole in amelioration of aflatoxicosis in broiler chickens. Iranian Journal of Applied Animal Science, 3(3): 595-603.

Singh R, Mandal A B and Divya. 2015 . Efficacy of methionine hydroxy analogue in ameliorating aflatoxicosis in Japanese quails. Animal Nutrition and Feed Technology, 15:227-34.

Singh R, Mandal A B and Shrivastav A K. 2013. Amelioration of aflatoxicosis in coloured broiler chickens by dietary butylated hydroxytoluene. Animal Nutrition and Feed Technology, 13:23542.

Singh R, Sharma M, Mandal A B and Tyagi P K. $2015^{\mathrm{b}}$. Efficacy of DL-Methionine in preventing aflatoxicosis in Japanese quails. Indian Journal of Poultry Science, 50(1):48-53.

Singh R, Sharma M, Mandal A B and Tyagi P K. 2016. Comparative efficacy of DLMethionine vis a vis methionine hydroxy analogue in ameliorating aflatoxicosis in Japanese quails. Indian Journal of Poultry Science, 51(2):16873.
Spires, H.R., R.L. Botts, and B.D. King. 1982. Methionine and choline supplementation of broiler diets for maximum profitability. Syntax Research Report, Series A, No. 1.

Thapa, N.K. (2008). Pathological effects of aflatoxicosis in layer chicken with special emphasis on reproductive pathology. M.V.Sc. Thesis submitted to Tamil Nadu Veterinary and Animal Sciences University.

Verma J, Johri T S, Swain B K and Ameena S. 2004. Effect of graded levels of aflatoxin, ochratoxin and their combinations on the performance and immune response of broilers. British Poultry Science45: 512-18.

Voight M N, Wyatt R D, Ayers J C and Koehler P. 1980. Abnormal concentrations of B vitamins and amino acids in plasma, bile and liver of chicks with aflatoxicosis. Application in Environmental Microbiology40: 870-75.

Xue, C.Y., Wang, G.H., Chen, F., Zhang, X.B. and Cao, Y.C. (2010). Immunopathological Effects of Ochratoxin A and T-2 Toxin Combination on Broilers. Poultry Science, 89: 1162-1166.

\section{How to cite this article:}

Ram Singh. 2019. Efficacy of Choline in Ameliorating Aflatoxicosis in Broiler Chickens. Int.J.Curr.Microbiol.App.Sci. 8(02): 2356-2365. doi: https://doi.org/10.20546/ijcmas.2019.802.274 